\title{
Kronik alkol kullanımı olan bir hastada kafa travmasını takiben gelişen penisiline dirençli pnömokok menenjiti
}

\section{Penicillin-resistant pneumococcal meningitis following a head trauma in a chronic alcoholic patient}

\author{
Kader ARSLAN, Salih CESUR*, Şükran SEVIM, Ayşe BÜYÜKDEMIRCi, Çiğdem Ataman HATiPOĞLU, Sami KINIKLI
}

Ankara Egitim ve Arastırma Hastanesi, Enfeksiyon Hastalıkları ve Klinik Mikrobiyoloji Kliniği, Ankara/TÜRKiYE

\begin{abstract}
öz
Kronik alkol kullanan bireylerde santral sinir sistemi infeksiyonu bulguları baskılanabilir veya alkol yoksunluk sendromu gibi klinik durumlarla karışabilir. Alkolik hastalarda mikroorganizmalara karşı immun yanıtın etkilenmesi, malnutrisyon ve vitamin eksikliği gibi nedenlerle infeksiyon etkenlerine karşı duyarlılık artar. Bu hastalarda en sık görülen menenjit etkeni Streptococcus pneumoniae'dır. Pnömokoklarda penisilin direnci son yıllarda tüm dünyada ve Türkiye'de önemli bir endişe kaynağıdır. Penisilineyüksek düzey dirençli pnömokokinfeksiyonlarının tedavisinde üçüncü kuşak sefalosporinler (seftriakson, sefotaksim) ve vankomisin kombinasyonu ile birlikte deksametazon tedavisi tercih edilir. Pnömokokal menenjitte tanı ve tedavide gecikme olması durumunda mortalite oranı yüksektir. Bu yazıda, kronik alkol kullanımı öyküsü olan 40 yaşında bir erkek hastada kafa travmasını takiben gelişen, geç tanı konulan ve mortal seyreden penisiline dirençli Streptococcus pneumoniae menenjiti olgusu sunuldu.
\end{abstract}

Anahtar kelimeler: Alkolik hasta; kafa travması; menenjit; penisiline dirençli pnömokok

\section{ABSTRACT}

Chronic alcohol use may suppress central nervous system infections or interfere with clinical conditions such as alcohol withdrawal syndrome. Sensitivity to infectious agents is increased in alcoholic patients due to the impaired immunological response to microorganisms, malnutrition and vitamin deficiency. The most common meningitis in these patients is Streptococcus pneumoniae. Penicillin resistance in pneumococci, is a major source of concern in recent years all over the world and in Turkey. In the treatment of pneumococcal infections, which are highly resistant to penicillin, a combination of third-generation cephalosporins (ceftriaxone, cefotaxime) and vancomycin is applied along with dexamethasone therapy. If there is a delay in the diagnosis and treatment of pneumococcal meningitis, the mortality rate is high. In this article, we present a 40-year-old male patient with chronic alcohol use history who was diagnosed with penicillin-resistant Streptococcus pneumoniae meningitis with delayed diagnosis and mortality which was developed after a head trauma.

Keywords: head trauma; meningitis; penicillin-resistant pneumococcus

Sorumlu Yazara: Salih Cesur, Ankara Egitim ve Arastırma Hastanesi, Enfeksiyon Hastalıkları ve Klinik Mikrobiyoloji Kliniği, Ankara/TÜRKiYE E-posta: scesur89@yahoo.com

Recevied: 20.09.2018 accepted: 20.10 .2018

Doi: $10.18663 / \mathrm{tjcl} .462004$ 


\section{Giriş}

Kronik alkol bağımlısı olan bireylerde en sık görülen menenjit etkenlerinden biri Streptoccoccus pneumoniae'dır. Kronik alkol kullanımı olan hastalarda gelişen menenjitlerde solunum yetmezliği ve nöbetin sık görülmesi, klinik tablonun alkol yoksunluk sendromu ile karışabilmesi nedeniyle tanısı güçtür ve tedaviye yanıt kötüdür. Pnömokoklarda penisiline direnç gelişimi önemli bir sorun olup, penisilin bağlayan proteinlerdeki yapısal değişiklik sonucu gelişir. Penisiline dirençli pnömokok infeksiyonlarının tedavisi güç, mortalite ve morbidite oranı yüksektir.

Bu yazıda alkol kullanımı olan bir hastada kafa travmasını takiben gelişen, tanı konulması geciken ve mortal seyreden penisiline dirençli pnömokok menenjiti gelişen 40 yaşında bir erkek hasta sunulmuştur.

\section{Olgu}

Kırk yaşında erkek hasta araç dışı trafik kazası nedeniyle dış merkezde acil servise başvurmuş, bir günlük gözlem sonrası taburcu edilmiş. Ertesi gün bilinç kaybı ve ajitasyon gelişen hasta aynı merkezin kabul etmemesi nedeniyle 48 saat sonra acil servisimize başvurmuş. Anamnezinde kronik alkol kullanımı ve diyabeti olduğu öğrenildi. Ateşi $39^{\circ} \mathrm{C}$, nabzı 88/ dk, KB 110/70 mmHg, genel durumu orta-kötü, şuuru açık, oryantasyon ve kooperasyonu kısıtlıydı. Ense sertliği, Kernig ve Brudzinski bulguları saptanan hastaya lomber ponksiyon (LP) yapıldı. Beyin omurilik sıvısı pürülandı, mikroskobisinde thoma lamında yoğun lökosit saptandı, Gram boyamasında Gram pozitif kok ve kokobasil görüldü. Beyin omurilik sıvısında protein $1570 \mathrm{mg} / \mathrm{L}$, laktat $19 \mathrm{mmol} / \mathrm{L}$, glikoz $0.4 \mathrm{mg} / \mathrm{dl}$, eş zamanlı kan şekeri 280 mg/dL, lökosit sayısı 23000/mm3 (\%95 nötrofil), sedimentasyon hızı $60 \mathrm{~mm} / \mathrm{saat}$ (normali 0-20 mm/ saat), prokalsitonin $31 \mu \mathrm{g} / \mathrm{L}$ (normali $\leq 0.5 \mu \mathrm{g} / \mathrm{L}$ ) , CRP:451 $\mathrm{mg} / \mathrm{L}$ normali 0-5 mg/L) idi. Hasta BOS ve kan kültürleri alındıktan sonra menenjit tanısıyla yatırılarak seftriakson $2 \times 2 \mathrm{~g}$, vankomisin $2 \times 1 \mathrm{~g}$, ampisilin 4x3g ve deksametazon 4x0.15mg/ kg başlandı. Deksametazon tedavisi iki gün süreyle uygulandı. BOS ve kan kültürlerinde S.pneumoniae üredi. Kan kültürü ve BOS kültüründen izole edilen S.pneumonaie suşu Phoenix otomatize sistemiyle (Becton-Dickinson, USA) penisiline dirençli, sefotaksime orta duyarlı, meropenem, kloramfenikole duyarlı olarak saptandı. BOS'dan izole edilen pnömokok suşunun penisilin için minimal inhibitör konsantrasyon (MiK) değeri Phoenix otomatize sistemiyle $0,12 \mu \mathrm{g} / \mathrm{ml}$ olarak rapor edildi. Ampisilin kesilerek diğer antibiyotiklere devam edildi. Tedavinin 7. gününde hastanın ateşinin tekrarlaması ve genel durumunun kötüleşmesi üzerine kontrol LP yapıldı. BOS ksantokromikti, yoğun lökosit görüldü, Gram boyamada mikroorganizma görülmedi. Aynı gün genel durumu kötüleşen hasta yoğun bakım ünitesine nakledildi, seftriakson tedavisi kesilerek vankomisin tedavisine meropenem $3 \times 2 \mathrm{~g}$ eklendi. Bilinci kapanan, solunumu kötüleşen hastanın beyin MR'ında serebrum ve serebellumda yaygın ödem saptandı. Mannitol ve deksametazon başlandı. Glaskow koma skalası 5'e gerileyen hasta entübe edildi. Tedavinin 18. gününde kardiyopulmoner yetmezlik sonucunda hasta kaybedildi.

\section{Tartışma}

S.pneumoniae, Gram pozitif, alfa hemolitik, safraya ve optokine duyarlı lanset şeklinde diplokoklardır. Pnömokoklar 5 yaş üzeri ve ileri yaş yetişkinlerde pnömoni ve bakteriyel menenjitin önemli bir etkenidir. Pnömokokal menenjit sıklıkla hematojen yolla gelişir, ancak sinüzit veya orta kulak infeksiyonundan sonra bakterinin direkt yayılımını takiben de gelişebilir. S.pneumoniae'ya bağIı bakteriyel menenjit meningokokal menenjit salgınları dışında bakteriyel menenjitin en sık etkenidir [1]. Kronik alkol bağımlısı olan hastalarda hücresel ve humoral immun yanıtların direkt olarak veya dolaylı olarak da karaciğer hastalığı sonucu malnütrisyon ve vitamin eksikliği nedeniyle etkilenmesi nedeniyle bakteriyel infeksiyonlara karşı artmış bir duyarlılık mevcuttur. Toplum kaynaklı menenjite en sık neden olan bakteri S. pneumoniae olup komplikasyon gelişme sıklığı ve mortalite oranı fazladır (2). Sunduğumuz olgu kronik alkol kullanımı olan ve 48 saat gecikme ile tanı konulan penisiline dirençli S. pneumoniae menenjiti olgusu idi ve mortal seyretti. Alkolik hastalarda gelişen pnömokokal infeksiyonların prognozu kötüdür ve mortalite oranı yüksektir [2,3] Leelarasamee ve ark. [4] hastanede yatan ve ciddi seyirli pnömokokal infeksiyonu olan 205 olguyu değerlendirdikleri çalışmalarında olguların \%51'inde pnömoni, \%21'inde akut $\mathrm{KOAH}$ alevlenmesi veya bronşiyolit, \%15'inde menenjit, \%8'inde odak saptanmayan sepsis tanısı koymuşlardır. İlk 7 günlük yatışta mortalite oranını \%29 olarak bildirmişlerdir.

Alkolik hastalarda menenjit klinik bulgularının aşırı abartılı olduğu ve mortalite oranının alkolik olmayanlardan daha yüksek olduğu bildirilmiştir [3]. Kronik alkol kullanımı olan hastalarda gelişen menenjitlerde solunum yetmezliği gibi sistemik komplikasyonların ve nöbetin sık görülmesi, klinik tablonun alkol yoksunluk sendromu ile karışabilmesi nedeniyle klinik yanıtın kötü olduğu rapor edilmiştir [2]. Sunduğumuz olguda ajitasyon ve bilinç kaybı başvurduğu dış merkezde kronik alkol kullanımıyla ilişkilendirilmiş olabilir. Bu nedenle de menenjit tanısının akla gelmemiş olması tanıda gecikmeye neden olmuş olabilir.

Weisfelt $M$ ve ark.[5] kültürle doğrulanmış bakteriyel menenjit gelişen 671 hastadaki bakteriyel menenjit epizodlarını değerlendirdikleri çalışmalarında hastaların 27'sinde (\%4) alkol bağımlılığı bildirmişlerdir. Çalışmada alkolik hastalarda alkolik olmayanlara göre yüksek oranda altta yatan pnömoni varlığı 
(alkolik olanlarda \%41, olmayanlarda \%11) saptanmıştır. Alkolik hastalarda en sık bakteriyel menenjit etkenleri; S. pneumoniae (\%70), Listeria monocytogenes (19\% ), Neisseria meningitidis (\%4) olarak bildirilmiştir. Alkolik hasta grubunda klinik seyir esnasında komplikasyon gelişme sıklığının alkolik olmayanlardan daha fazla olduğu ve sıklıkla da kardiyak ve solunum yetmezliği geliştiği bildirilmiştir. Sunduğumuz olgu da tedavinin 18.gününde kardiyopulmoner yetmezlik sonucunda kaybedilmiştir.

Hollanda'da veen KEB ve ark.[2] 88 alkolik hastada yaptıkları çaIışmada semptomların başlangıç süresini 40 hastada (\%56) 24 saatten uzun olarak bildirmişlerdir. Bu çalışmada ateş olguların \%74'ünde, başağrısı \%64'ünde, ense sertliği \%59'unda, fokal nörolojik defisit \%32'sinde, septik şok bulguları \%31'inde, kraniyal sinir paralizisi ise \%11'inde saptanmıştır. Beyin görüntüleme incelemelerinde; olguların \%31'inde anormal bulgu saptanırken, \%23 olguda otit veya sinüzit saptanmıştır. Olguların tümünde BOS lökosit sayısı artmış (ortalaması 1765 hücre), BOS proteini artmış, BOS glukozu düşük saptanmıştır. Olgularda BOS kültüründen en sık izole edilen bakteriler; 67 olguda (\%76) S. pneumoniae, 7 olguda (\%8) L. monocytogenes, 5 olguda (\%6) N. meningitidis, diğer olgularda ise Staphylococcus aureus, Streptococcus agalactiae ve diğer bakteriler olarak rapor edilmiştir. Olguların başlangıç başvurusunda solunum yetmezliği, endokardit ve pnömoni sıklığı alkolik olmayan hastalara oranla yüksek oranda saptanmıştır. Alkolik hastalarda mortalite oranı \%58 oranında saptanırken, alkolik olmayan kohort grubunda \%34 olarak bildirilmiştir. Sunduğumuz olguda muhtemelen alkole bağlı olarak klinik semptomların baskılanması sonucu, hastada alkolle ilişkili klinik durumlar düşünülmüş, bu nedenle tanı ve tedavisi gecikmiş ve hasta mortal seyretmiştir.

Pnömokokal menenjit hayatı tehdit eden bir infeksiyondur, bu nedenle acil tanı konulması ve tedavi edilmesi gerekir. Pnömokoklarda bildirilen penisilin direnci önemli bir endişe nedenidir [6].

Pnömokoklarda penisilin direnci penisilin bağlayan proteinlerde genetik yapısal değiş̧iklik sonucu ortaya çıkar [1,7].

İnvaziv pnömokokal hastalıklar (pnömoni, menenjit, sepsis vb.) iyi tedavilere rağmen hızla mortal seyreder. Gelişmiş ülkelerde pnömokokal menenjitli hastalarda mortalite oranı \%20 iken, gelişmekte olan ülkelerde bu enfeksiyon hastane koşullarında bile \%50 mortal seyreder [8].

Verghese ve ark. [6] pnömokok menenjiti olan hastalardan izole edilen pnömokok suşlarında penisilin direncini \%44, sefotaksim direncini ise \%15 olarak bildirmişlerdir. Sunduğumuz olguda da BOS kültüründen penisiline yüksek dirençli (MiK: $0,12 \mu \mathrm{g} / \mathrm{ml}$ ) S. pneumoniae izole edilmiştir

Erdem ve ark.[9] pnömokok menenjiti olan toplam 306 hasta- da yaptıkları çalışmada 246 (\%79) izolat penisiline duyarlı, 38 (\%12) izolat penisiline dirençli, 22 (\%7) izolat ise oksasiline dirençli saptanmıştır. Çalışmada seftriaksonun penisiline dirençli pnömokoklardan ötürü tek başına pnömokokal menenjitte yeterli olmadığı, kritik hastalar ve 50 yaş üzerinde olmanın mortalite için bağımsız risk faktörü olduğu bildirilmiştir.

Toplum kaynaklı menenjit olgularında yapılan bir prospektif çaIışmada 1412 bakteriyel menenjit epizodunun 1017'sinin (\%72) pnömokoklara bağlı olarak geliştiği bildirilmiştir. Aynı çalışmada, istenmeyen sonuçlarla ilgili belirleyiciler; ileri yaş, otit veya sinüzit olmaması, alkolizm, taşikardi, Glaskow koma skorunun düşük olması, kraniyal sinir paralizisi, BOS'da hücre sayısının 1000/ $\mu \mathrm{L}$ altında olması, pozitif kan kültürü, yüksek CRP seviyesi olarak rapor edilmiştir. Tedaviye deksametazon eklenmesinin kalıcı iyi yanıt elde edilmesiyle ilişkili olduğu da saptanmıştır [10]. Sunduğumuz olguda kötü klinik yanıtla ilişkili olarak alkolizm varlığı, kan kültürü pozitifliği ve CRP yüksekliği mevcuttu.

Penisiline orta duyarlı veya dirençli suşların neden olduğu olası veya kesin pnömokokal menenjitli olguların tedavisinde duyarlılık sonuçları çıkana kadar üçüncü kuşak sefalosporinlerin (seftriakson, sefotaksim) vankomisinle kombinasyonu önerilir [11].

Sunduğumuz olguda penisiline direnç bildirilmesi nedeniyle vankomisin tedavisine devam edildi. Ayrıca hastaya başlangıçtan itibaren deksametazon tedavisi de verildi.

Klinik ve Laboratuvar Standartları Enstitüsü'nün (CLSI) BOS'tan elde edilen izolatlar için, parenteral kullanılan penisilin MiK direnç sınır değeri $\geq 0.12 \mu \mathrm{g} / \mathrm{ml}$ olarak değişmiştir. BOS dışındaki izolatlar için penisilin MiK değerleri, $\geq 8 \mu \mathrm{g} / \mathrm{ml}$ olduğunda penisiline dirençli pnömokok, $4 \mu \mathrm{g} / \mathrm{ml}$ olduğunda penisiline orta duyarlı pnömokok ve $\leq 2 \mu \mathrm{g} / \mathrm{ml}$ olduğunda penisiline duyarlı pnömokok olarak değerlendirilmektedir [12]. Sunduğumuz olguda BOS'dan izole edilen S.pneumoniae izolatında MiK değeri $\geq 0.12 \mu \mathrm{g} / \mathrm{ml}$ olarak belirlendiğinden olgumuz penisiline dirençli pnömokok menenjiti olarak değerlendirildi. Bu nedenle ampirik olarak başlanan vankomisin tedavisine devam edildi.

Taşova ve ark. [13] 29 yaşında kadın hastada çok ilaca dirençli pnömokok menenjiti bildirmişlerdir. Hastadan izole edilen pnömokok suşunun otomatize sistemle belirlenen penisilin ve seftriakson duyarlılıkları sırasıyla; $2 \mu \mathrm{g} / \mathrm{ml}$ ve $0,5 \mu \mathrm{g} / \mathrm{ml}$ olarak bildirilmiştir. Seftriakson tedavisinin 6. gününde ateş ve konfüzyonu gelişen hastada LP yapılmış, BOS'da 640 hücre/mm3 (\%75 polimorfo nükleer lökosit) olması üzerine tedaviye vankomisin eklenmiştir. Vankomisin tedavisinden sonra ateşi düşen ve genel durumu düzelen hastanın tedavisi 14 güne tamamlanmıştır. Sunduğumuz hastada başlangıçta penisiline dirençli pnömokokların da etken olabileceği düşünülerek ampirik tedavide van- 
komisin kullanıldı. Hastanın kliniğimize gelene kadar gecikmesi, muhtemel menenjit semptomlarının alkol kullanımı nedeniyle akla gelmemesi hastada tanıda gecikmeye neden olmuştur. Sonuç olarak, penisilin dirençli pnömokok riski olan hastalarda menenjit tanısı konulduğunda ampirik olarak vankomisin tedavisinin de başlanması önerilmektedir. Erken vankomisin tedavisine rağmen hastanın kaybedilmesi tanı-tedavide gecikme, alkol kullanımı ve kafa travması gibi komorbid durumlara bağlanmıştır.

\section{Çıkar çatışması / finansal destek beyanı}

Çalışmayı maddi olarak destekleyen kişi / kuruluş yoktur ve yazarların çıkara dayalı bir ilişkisi yoktur.

\section{Kaynaklar}

1. Edward N. Janoff and Daniel M. Musher. Streptococcus pneumoniae. Mandell, Douglas, and Bennett's Principles and Practice of Infectious Diseases, Updated Edition, 2015; 2310-2327.e5.

2. Van Veen KE, Brouwer MC, van der Ende A, van de Beek D. Bacterial meningitis in alcoholic patients: A population-based prospective study. J Infect 2017; 74 : 352-57.

3. Kim AC, Epstein ME, Goyal PG, Doan TL. Infections in Alcoholic Liver Disease. Clin Liver Dis 2012; 16: 783-803.

4. Leelarasamee A, Dhiraputra C, Hunnangkul S. Severe pneumococcal infection at a Thai hospital. Int J Infect Dis 1999; 3: 147-52.

5. Weisfelt M, de Gans J, van der Ende A, van de Beek D. Community-acquired bacterial meningitis in alcoholic patients. PLoS One 2010; 5: 9102.
6. Verghese VP, Veeraraghavan B, Jayaraman R, Varghese R, Neeravi A, Jayaraman Y, Thomas K, Mehendale SM. Increasing incidence of penicillin- and cefotaxime-resistant Streptococcus pneumoniae causing meningitis in India: Time for revision of treatment guidelines? Indian J Med Microbiol 2017; 35: 228-36.

7. Cherazard R, Epstein M, Doan TL, Salim T, Bharti S, Smith MA. Antimicrobial Resistant Streptococcus pneumoniae: Prevalence, Mechanisms, and Clinical Implications. Am J Ther 2017 ; 24: 361-69.

8. Muley VA, Ghadage DP, Yadav GE, Bhore AV. Study of Invasive Pneumococcal Infection in Adults with Reference to Penicillin Resistance. J Lab Physicians 2017 ; 9: 31-35.

9. Erdem $\mathrm{H}$, Elaldi $\mathrm{N}$, Öztoprak $\mathrm{N}$ et al. Mortality indicators in pneumococcal meningitis: therapeutic implications. Int J Infect Dis $2014 ; 19: 13-19$.

10. Bijlsma M, Matthijs $C$ Brouwer, E et al. Community-acquired bacterial meningitis in adults in the Netherlands, 2006-14: a prospective cohort study. Lancet Infect Dis 2016; 16: 339-47.

11. Hameed N, Tunkel AR. Treatment of drug-resistant pneumococcal meningitis. Curr Infect Dis Rep 2010 ; 12: 274-81.

12. Clinical and Laboratory Standards Institute. Performance standards for antimicrobial susceptibility testing; 20thInformational Supplement, 2010, M100-S20. CLSI, Wayne, PA.

13. Taşova Y, Saltoğlu N, Dündar IH. Çok ilaca dirençli pnömokokal menenjit: bir olgu sunumu.Flora Dergisi 1998; 3: 134-39. 